\title{
The Effects of Blended Instruction on Oral Reading Performance and their Relationships to a Five-Factor Model of Personality
}

\author{
Noritake Fujishiro* \\ Okayama Pref. Center of Education, Japan \\ 7545-11 Yoshikawa, Kibi Chuo-Cho, Kaga-Gun, Okayama Prefecture, \\ 716-1241 Japan \\ E-mail: noritake_fujishiro@pref.okayama.lg.jp
}

Isao Miyaji

Faculty of Informatics,

Okayama University of Science, Japan

1-1 Ridai-cho, Kita-ku, Okayama City, 700-0005 Japan

E-mail: miyaji@mis.ous.ac.jp

*Corresponding author

\begin{abstract}
In recent times, 'Blended Instruction' - an effective method of instructions utilizing e-Learning materials in English education - consists of an individual learning part, a collaborative learning part and a teacher instruction part. In the individual learning, students act out model dialogues in the WBT courseware which incorporated a high quantity of video and sound clips. In the collaborative learning, students perform the dialogues in pairs and assessed each other's performance. Our recent research in a high school showed that the skill of the students' oral reading was improved in most criteria of assessment through blended instruction. However, it is still not clear what kind of relationship exists between the development of the students' oral reading skills and their personalities. With this in mind, the authors have studied the effects of the blended instruction on the junior high school students' oral reading performance and their relationships to the five-factor model of personality. The result of the research shows that the skill of the students' oral reading was improved in most criteria of assessment and the blended instruction was effective for the personality group, 'Introverted unintelligent person' in the most categories of oral reading criteria as well as the personality group, 'Sociable hard-worker'. The important factor for that group in oral reading performance turned out to be 'Sense Reading'.
\end{abstract}

Keywords: Blended Instruction, Foreign Language Education, Oral Reading Performance, WBT, Five-Factor Model.

Biographical notes: Noritake Fujishiro received Ph.D. degree from Okayama University of Science. He is a teacher consultant of Okayama Prefectural Center of Education, Japan. He has been researching on the effects of Blended learning utilizing WBT courseware on students' English proficiency.

Isao Miyaji received Ph.D. of Engineering from Kyoto University. He is a professor with Faculty and Graduate School of Informatics of Okayama University of Science. His research interests are in blended learning and 
improvement of the instruction technique with ICT. He is a president at Chugoku Branch of JSSE.

\section{Introduction}

One of the main aims of English education at junior high school and high school in Japan is to develop students' practical communication skills. However, it is quite difficult for teachers to instruct their students individually in listening and speaking activities, because teachers do not have the time to devote their attention to each student in turn. In order to improve this situation, e-Learning has been greatly focused on in recent years in Japan.

Widdowson (1978) defined that speaking is an auditory and visual activity. For instance, nonverbal information, such as gestures and facial expressions, can be conveyed as visual information in the process of sending and receiving messages. According to the McGurk effect, comprehending a situation with a visual cue could make a listening comprehension much easier (McGurk, 1976). According to the Dual-coding theory (Clark and Pavio, 1991), visual and verbal information are processed respectively in each channel according as the kind of incoming information and cognitive resources can be used most effectively by synchronizing visual and verbal codes because the visual and verbal information does not compete with each other.

With this in mind, the authors developed a WBT courseware which includes a large quantity of video and sound clips as visual and verbal aids for an individual conversation practice (Fujishiro \& Miyaji, 2007a). The students could make a virtual conversation practice with it effectively before making a real conversation.

Fujishiro et al. (2007b) reported that the listening ability improved for students with both low and high English proficiency and that less motivated students became more positive through 'Blended learning lessons' in a junior high school, which consisted of an individual learning part in which students complete a model dialogue in the original WBT courseware, a collaborative learning part in which the students perform the dialogues in pairs and assess each other's performance and a teacher's scaffoldings part.

According to our previous study in a high school (Fujishiro \& Miyaji, 2008), the students' oral reading skill was improved and their motivation toward expressing themselves in English was developed through blended learning with WBT courseware. However, there was no investigation into the relationship between the development of the students' oral reading skill and their personality.

This paper investigates how the blended instruction with WBT courseware in a class at a junior high school level enhances students' oral reading skill phonetically and how the oral reading skill of personality groups classified according to the five-factor model is improved. This paper also investigates the important factors for each personality group in oral reading performance.

\section{Background of the Study}

\subsection{Utilization of WBT and the Shadowing Activity}

In the process of improving English listening comprehension and speaking skill, it is important to have practical experiences with multimedia materials (Scanlon, 1997) which help practice pronouncing the conversation and have a virtual conversation. 
Rivers (1972) put the process of language learning with multimedia materials into a diagram which showed the steps from skill-getting to skill-using. Paulston (1992) reconstructed it into three steps; step 1 was a mechanical drill, step 2 was a meaningful drill and step 3 was communicative drill. Based on this, Takanashi (1992) classified activities in English classes into four steps from A to D; Step A consisted of mechanical and meaningful drills, Step B was a communicative drill, Step C meant information gap activities and Step D consisted of role play and simulation, and reported that the level of meaningfulness and creativity of activities became higher in alphabetical order.

In terms of procedure of instruction, Koike et al. (1994) proposed three stage instructional approach; the 1st stage was 'comprehension' of the vocabulary, grammar and expression, the 2nd stage was 'drill' of pronunciation and sentence patterns which included copying a conversation and repetitive practice, and the 3rd stage was 'application' which included controlled conversation practice and collaborative communication activity. It could be thought that the notion of "mimicry-memorization practice" was applied to 'copying a conversation' practice in the 2nd stage and the utilization of a high quantity of video and sound clips in the WBT courseware for acting out model dialogues is useful.

Tamai (2005) reported that listening ability improved for students with middle and low English proficiency through "Shadowing" activities, where the students repeated the phrases from a conversation model almost simultaneously. Mochizuki (2004) reported the shadowing activity was effective in developing the students' oral reading performance.

With this in mind, the authors utilized the WBT courseware developed in 2006 (Fujishiro \& Miyaji, 2007a), to assist the students' individual shadowing activity and virtual conversation. As procedure of instruction, the authors took three stage instructional approach, 'Comprehension', 'Drill' and 'Application'. The WBT material is made up of four stages per topic; the four stages consist of 'Reading', 'Conversation Practice', 'Expressing Ideas', and 'Let's Talk'. As for characteristics, the WBT courseware has a large quantity of video and sound clips as conversation models and learners can easily practice acting out their own part of the dialogue to a conversation model as shown in Figure1.

In this study, the shadowing activity was conducted on every lesson using numerous video and sound clips in the WBT courseware as a 'Conversation Model' for self-practice on each topic.



Figure 1. Conversation Model 


\subsection{Definition of Blended Instruction}

The instructional approach of "Blended Instruction" is based on the notion of Blended Learning. Usual blended instruction is the combination of face-to-face instruction "inside" the classroom and the e-Learning "outside" the classroom (Bonk \& Graham, 2006). For instance, Miyaji et al. (2005) reported the effectiveness of this kind of blended instruction in which lectures and e-learning outside the lecture were combined in the university. On the other hand, there is another definition for blended learning, in which blended instruction means the combination of various style of learning activities (Gagne 2005). In terms of utilization of e-learning at a junior high school, an individual learning part with WBT courseware at their own pace can be blended and well-balanced with other styles of learning activity in a classroom.

Wilson (2005) examined the combination of e-learning and lessons; 'e-learning before a lesson', 'e-learning in a lesson' and 'e-learning after a lesson', and reported that 'e-learning in a lesson' is effective for presentation of new materials and review as students have access to a teacher's instruction and can receive feedback.

As shown in Figure2, the components of the blended instruction in this study consist of three learning parts, students' individual learning part with a WBT courseware, a collaborative learning part and a teacher's face-to-face instruction part (Fujishiro \& Miyaji, 2009a). Fujishiro et al. (2007b) reported that it was appropriate in a junior high school to combine those three learning parts in one learning opportunity in terms of maintaining students' motivation toward learning and individualization of learning. The instructional mode in which those three parts are combined "inside" the classroom is called "Blended Instruction" in this study.

In this blended instructional mode, collaborative learning part in pairs is based on the notion of peer tutoring (Goodlad 1985), where students learn through instructing each other what is wrong, and the notion of peer assessment (Davies 1999), where students assess each other's performance. Collaborative learning in pairs or in groups would be effective in language acquisition as it helps increase interactions among students and both input and output in the classroom (Pica \& Doughty, 1985). This style of blended instruction, which includes collaborative learning, has been highly evaluated and widely recognized recently (Gagne et al., 2005, p.334). The teacher's instruction in this combination was based on the notion of teacher's appropriate scaffolding for students in the Vygotsky's theory (Van Der Stuyf 2002).

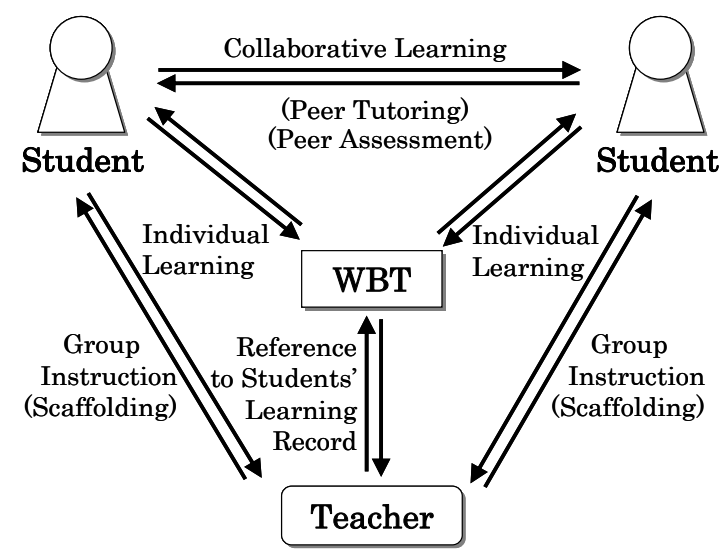

Figure 2. Blended Instruction Model (Fujishiro \&Miyaji, 2009) 


\subsection{The Five-Factor Model of Personality}

The personality of each student is different and it is thought to have an influence on the learning effect. Nunomura \& Murakami (1996) reported that the factors of personality had significant correlations with English speaking and listening tests. It is important to examine the key factors of the students' personality in verifying the effects on oral reading performance through blended instruction.

In the field of personality psychology, Allport and Odbert (1936) provided the original source of personality-related terms by listing about 18,000 descriptors found in an unabridged English dictionary (McAdams, 1992). Through a series of steps, Tupes and Christal (1961) suggested only five replicable factors. Across a wide variety of studies involving trait-descriptive terms, five broad factors have consistently been found (Goldberg, 1992). The general consensus has been that the basic dimensions of personality were made of five factors (Wiggins \& Trapnell, 1996). These factors build the so called 'Big Five' or Five-Factor model. The five-factor consists of "Extroversion", "Agreeableness", "Conscientiousness", "Neuroticism", "Openness". In this study, the students were classified into four groups based on this five-factor model and the degree of development in each category of oral reading criteria was examined.

\section{Research Methods}

\subsection{Participants}

In the Experiment 1 at the T Junior High School in Okayama Prefecture in Japan during the school year 2008, blended learning group with WBT (Experimental group) consisted of 31 third year students that belonged to advanced classes of the subject 'English,' and the control group consisted of 30 third year students that belonged to intermediate classes of the subject 'English.'

In the Experiment 2 at the U Junior High School in Okayama Prefecture during the school year 2009, blended learning group with WBT (Experimental group) consisted of 94 third year students that belonged to class A, B or C and the control group consisted of 68 third year students that belonged to class $\mathrm{D}$ or E.

However, the valid number of students analyzed is lower because of absence.

\subsection{Research on the Effects through Blended Instruction}

In order to measure the oral reading skill, three levels of material for oral reading tests were prepared; Word (four words), Sentence (two sentences $\times$ two), Passage (Passage consisted of 66 words). These materials were formed from the list of words and sentences which were proposed by Endou (2005) based on the British National Curriculum. The materials were chosen so that it might not be difficult for the students to read them aloud smoothly.

In order to assess how the blended learning with WBT courseware worked in terms of oral reading performance, the we set four levels of criteria; word, sentence, passage and total level, and categories in each level, as shown in Table 1 and recorded the students reading aloud task materials using a digital video recorder before and after the lessons. In the Experiment 1, two raters, an ALT (Assistant Language Teacher) who was a native speaker of English and a JTE (Japanese Teacher of English), discussed and scored the students' performance watching the recorded students' oral reading performance from 5 to 1; 5:Excellent, 4:Good, 3:Average, 2:Poor, 1:Very Poor. In the Experiment 2, the two raters, an ALT and a JTE, scored the students' performance 
separately watching the recorded students' oral reading performance from 5 to 1 ; 5:Excellent, 4:Good, 3:Average, 2:Poor, 1:Very Poor, so that the assessments by the two raters might not be mutually influenced and the average score of the two raters was calculated out to be the assessment score of oral reading skill.

In order to verify the effect on the students' mental aspect, pre and post surveys were carried out. As shown in Table 2, each survey in Experiment 1 consisted of 24 questions, out of which 22 questions were multiple-choice, each with five possible answers given. The multiple-choice questions were scored from 5 to 1 as in the previous study (Fujishiro \& Miyaji, 2007c). As shown in Table 3, each survey in Experiment 2 consisted of 25 questions, out of which 22 questions were multiple-choice, each with five possible answers given. The multiple-choice questions were scored from 5 to 1 in the same way as Experiment 1.

\section{Table 1. Oral Reading Assessment Criteria}




Table 2. Survey in Experiment 1

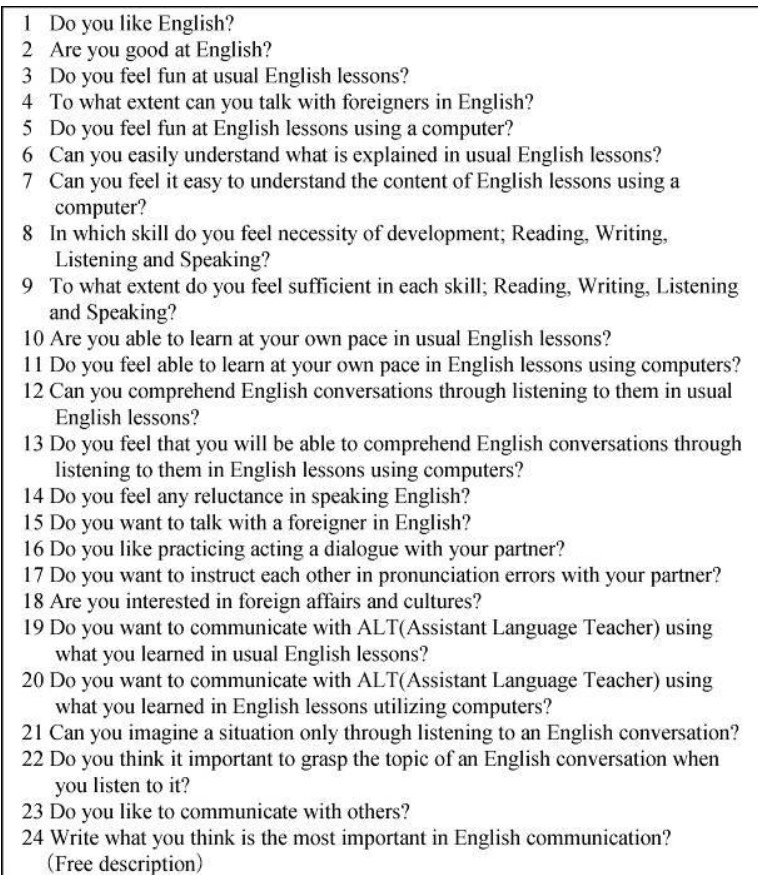

Table 3. Survey in Experiment 2

1 Do you like English?

2 Are you good at English?

3 Do you feel fun at usual English lessons?

4 Do you feel fun at English lessons using a computer?

5 To what extent can you talk with foreigners in English?

6 Can you easily understand what is explained in usual English lessons?

7 Can you feel it easy to understand the content of English lessons using a computer?

8 Do you take a positive attitude toward learning English?

9 Do you help each other communicating with other people?

10 In which skill do you feel necessity of development; Reading, Writing,

Listening and Speaking?

11 To what extent do you feel sufficient in each skill; Reading, Writing, Listening and Speaking?

12 Are you able to learn at your own pace in usual English lessons?

13 Do you feel able to learn at your own pace in English lessons using computers?

14 Can you comprehend English conversations through listening to them in English lessons?

15 Do you feel any reluctance in speaking English?

16 Do you want to talk with a foreigner in English?

17 Do you like practicing acting a dialogue with your partner?

18 Do you want to instruct each other in pronunciation errors with your partner?

19 Do you feel it useful to practice acting dialogues to the model dialogues in video clips in terms of putting it practical use?

20 Do you feel it suitable for you to learn English using a computer?

21 Are you interested in foreign affairs and cultures?

22 Can you imagine a situation only through listening to an English conversation?

23 Do you think it important to grasp the topic of an English conversation when you listen to it?

24 Choose one activity which you think is the most effective for you to improve your English conversation skill; 1. Conversation practice in pairs, 2. Individual conversation practice using computer, 3 . Chorus reading of dialogues

25 Write what you think is the most important in English communication? (Free description) 


\subsection{Classification based on Personality}

In order to clarify what kind of personality groups existed and for what kind of personality groups the blended instruction was effective, the students were advised to take the BigFive personality survey (Murakami \& Murakami, 2001) which consisted of $70 \mathrm{Yes} /$ No questions. Using the computer personality judging system, 'BigFive', which was developed by Murakami et al. (2001), the scores for the five-factors were calculated. Based on the scores, the students could be classified into some clusters based on the principal component analysis and the cluster analysis (Fujishiro \& Miyaji, 2009b).

\section{Experiments and Results}

\subsection{The Blended Learning Lessons}

The blended learning lessons with WBT courseware were carried out at two junior high schools in Okayama Prefecture in Japan. Six English lessons were assigned to the third year students for that purpose on each school. Experiment 1 at T Junior High School was during the period Sept. 29th to Dec. 1st, 2008. The blended learning lessons were conducted in two classes, consisting of 31 students in total. Experiment 2 at the U Junior High School was completed during the period Oct. 23rd to Nov. 16th, 2009. The blended learning lessons were conducted in three classes, consisting of 94 students in total.

The main learning style, instructional step and activities of blended instruction are shown in Figure 3. Nine instructional steps and activities were set according to Gagne's 'Nine Instructional Steps' (Gagne et al., 2005, p.248). Especially at the 6th step 'Elicit Performance', individual conversation practice utilizing the WBT courseware at students' own pace and collaborative learning in pairs using the dialogue completed in the individual practice were combined.

\begin{tabular}{|c|c|}
\hline Learning Style & Instructional Step and Activity \\
\hline $\begin{array}{c}\text { Group } \\
\text { (whole Class) }\end{array}$ & $\begin{array}{l}\text { 1. Gain Attention of Learner } \\
\text { 2. Inform Learner of Objective }\end{array}$ \\
\hline $\begin{array}{l}\text { Individual } \\
\text { (WBT) }\end{array}$ & $\begin{array}{l}\text { 3. Stimulate Recall of Prerequisites } \\
\text { Individual Learning: } \\
\text { Listening Comprehension Check }\end{array}$ \\
\hline $\begin{array}{c}\text { Group } \\
\text { (Whole Class) }\end{array}$ & \multirow{5}{*}{$\begin{array}{l}\text { 4. Present Stimulus Material } \\
\text { 5. Provide Learning Guidance } \\
\text { Chorus reading } \\
\text { Oral reading in pairs } \\
\text { 6. Elicit Performance } \\
\text { Individual conversation practice } \\
\text { (Shadowing) } \\
\text { Acting out dialogues in pairs } \\
\text { Mutual assessment } \\
\text { 7. Provide Feedback }\end{array}$} \\
\hline Pair & \\
\hline $\begin{array}{l}\text { Individual } \\
\text { (WBT) }\end{array}$ & \\
\hline Pair & \\
\hline $\begin{array}{c}\text { Group } \\
\text { (Whole Class) }\end{array}$ & \\
\hline $\begin{array}{l}\text { Individual } \\
\text { (WBT) }\end{array}$ & \multirow{3}{*}{$\begin{array}{l}\text { 8. Assess Performance } \\
\text { Expressing one's own opinion } \\
\text { about topics }\end{array}$} \\
\hline Pair & \\
\hline $\begin{array}{c}\text { Group } \\
\text { (whole Class) }\end{array}$ & \\
\hline
\end{tabular}

Figure 3. Instructional Mode and Steps of Blended Instruction (Fujishiro \&Miyaji, 2009) 
The procedure during the lessons considered the following steps:

- Listening Comprehension Check; Listening and answering the questions (WBT)

- Teacher's Instruction; the teacher gives instructions about useful expressions (Class)

- Conversation Practice with WBT courseware; Listening to the conversation model in the WBT courseware and acting out the dialogue with the model (WBT)

- Conversation Practice; Acting out the dialogue with a partner and peer assessment (Pair work)

- Presentation; Acting out the dialogue in front of other students (Class)

In the control group, the same content was taught entirely by a teacher instead of by individual conversation practice utilizing WBT courseware and collaborative learning in pairs.

\subsection{Results of the Study}

\subsubsection{The Personality Groups}

The principal component analysis was conducted using the five-factor scores from the BigFive personality survey in Experiment 1 and Experiment 2. In Experiment 1, the first and second principal components accounted for $36.4 \%$ and $31.0 \%$ of the total variance. The first principal component was interpreted as "Sociality', as "Extroversion", "Agreeableness" and "Neuroticism" of five-factors were greatly related to it. The second principal component was interpreted as 'Intelligence', as "Conscientiousness" and "Openness" were greatly related to it.

In Experiment 2, the first and second principal components accounted for $30.1 \%$ and $25.4 \%$ of the total variance. The first principal component was interpreted as 'Sociality' and the second principal component was interpreted as 'Intelligence' in the same reason as Experiment 1.

By the cluster analysis, the students were classified into four groups, shown in Figure 4 and Figure 5. The Group 1, shown in Figure 4 and Figure 5 as the ' $\mathrm{Cl} 1$ ', was referred to as 'Introverted hard-worker', the Group 2, as the ' $\mathrm{Cl} 2$ ', 'Sociable hardworker', the Group 3, as the ' $\mathrm{Cl}$ 3', 'Sociable but unintelligent person', the Group 4, as the ' $\mathrm{Cl}$ 4', 'Introverted unintelligent person.'
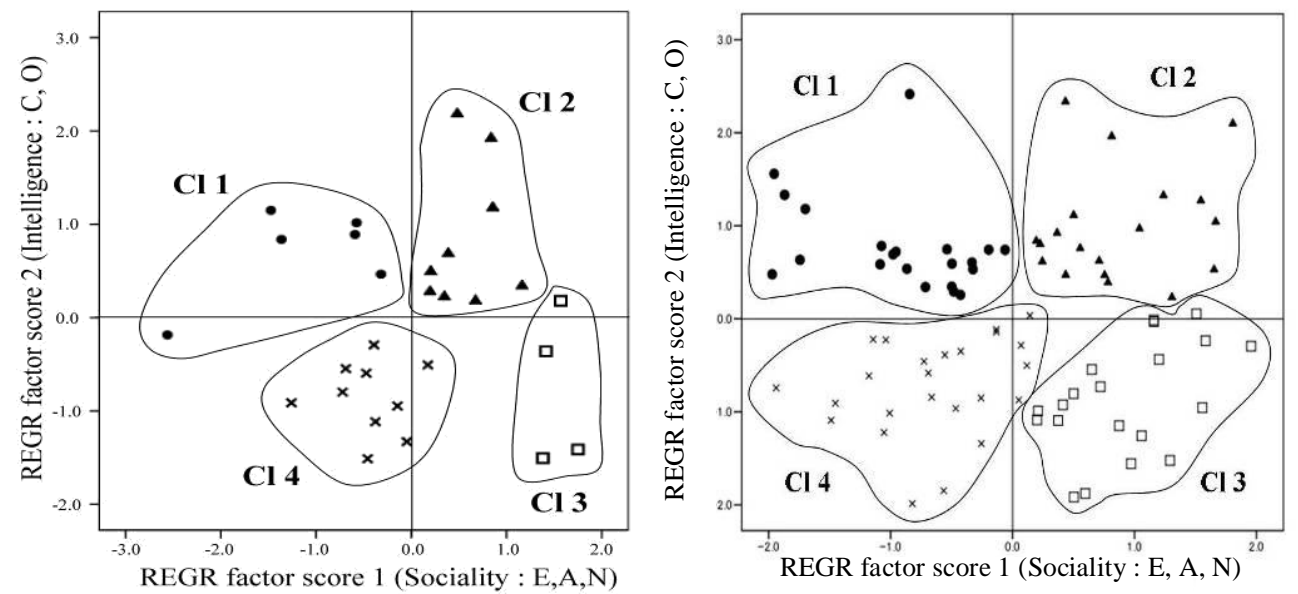

Figure 4. Personality Groups in Experiment 1 Figure 5. Personality Groups in Experiment 2 


\subsubsection{The Development of the Oral Reading Skill and the Personality Groups}

The authors compared the scores of the pre and post oral reading performance tests in Experiment 1. As shown in Table 4, the result of the t-tests shows that the most categories of oral performance except the category 'Attitude', 'Volume' and some categories were improved at the significance level of $10 \%$ to $0.1 \%$, where $n$ is the number of valid responses, SD stands for standard deviation. Sig. means Significance.

In terms of educational effects on each personality group, the authors also compared the scores of pre and post oral reading performance test in each group in Experiment 1. As shown in Table 4, the result of the Wilcoxon signed-rank test shows that the oral reading skill of the Group $4(\mathrm{Cl} 4)$ developed significantly in the most categories of all the groups. The group whose oral reading skill developed significantly in the second most categories of all the groups was the Group $2(\mathrm{Cl} 2)$.

After the degree of development in each category of oral reading criteria in Table 4 was calculated through subtracting the pre-score from the post-score, factor analysis was conducted for all the 24 categories using unweighted least squares method and varimax rotation in order to clarify the factors which contributed to the development. The authors set the number of factors at four in terms of comparison with Experiment 2. Four factors extracted are shown in Table 5. The contribution ratio was $61.0 \%$ in total.

Factor 1 was interpreted as "Pronunciation of Passage" because it related to the categories of 'Passage level.' In the same way, Factor 2 was interpreted as "Attitude and Volume". Factor 3 was interpreted as "Pronunciation of Sentence". Factor 4 was interpreted as "Pronunciation of Word".

Table 4. The Improvement of the Oral Reading Performance and the Personality Group (Experiment 1)

\begin{tabular}{|c|c|c|c|c|c|c|c|c|c|c|c|c|c|c|c|}
\hline \multirow{2}{*}{ Criteria } & \multirow{2}{*}{ Level } & \multicolumn{2}{|c|}{$\begin{array}{l}\begin{array}{c}\text { Pre-test } \\
(\mathrm{n}=29)\end{array} \\
\end{array}$} & \multicolumn{2}{|c|}{$\begin{array}{l}\text { Post-test } \\
(\mathrm{n}=29)\end{array}$} & \multicolumn{2}{|c|}{ t-Test } & \multicolumn{2}{|c|}{$\begin{array}{c}\mathrm{Cl} 1 \\
(\mathrm{n}=6)\end{array}$} & \multicolumn{2}{|c|}{$\begin{array}{c}\mathrm{Cl} 2 \\
(\mathrm{n}=9)\end{array}$} & \multicolumn{2}{|c|}{$\begin{array}{c}\mathrm{Cl} 3 \\
(\mathrm{n}=4)\end{array}$} & \multicolumn{2}{|c|}{$\begin{array}{c}\mathrm{Cl} 4 \\
(\mathrm{n}=10)\end{array}$} \\
\hline & & mean & SD & mean & SD & $\begin{array}{c}\text { Value } \\
\text { of } \mathrm{t}\end{array}$ & \begin{tabular}{|c|}
$\begin{array}{c}\text { Sig. } \\
\text { level }\end{array}$ \\
\end{tabular} & $\begin{array}{l}\text { Value } \\
\text { of } Z \\
\end{array}$ & \begin{tabular}{|c|}
$\begin{array}{c}\text { Sig. } \\
\text { level }\end{array}$ \\
\end{tabular} & $\begin{array}{l}\text { Value } \\
\text { of } Z\end{array}$ & \begin{tabular}{|c|}
$\begin{array}{c}\text { Sig. } \\
\text { level }\end{array}$ \\
\end{tabular} & $\begin{array}{l}\text { Value } \\
\text { of } Z \\
\end{array}$ & \begin{tabular}{|c|}
$\begin{array}{c}\text { Sig. } \\
\text { level }\end{array}$ \\
\end{tabular} & $\begin{array}{l}\text { Value } \\
\text { of } Z\end{array}$ & \begin{tabular}{|c|}
$\begin{array}{c}\text { Sig. } \\
\text { level }\end{array}$ \\
\end{tabular} \\
\hline \multirow{2}{*}{ Liais on } & Sentence & 2.2 & 0.8 & 3.4 & 0.6 & 11.6 & **** & 2.4 & * & 2.6 & *** & 1.9 & + & 2.8 & *** \\
\hline & Passage & 2.3 & 0.8 & 3.3 & 0.6 & 7.6 & $* * *$ & 2.2 & * & 2.4 & * & 1.6 & & 2.5 & $*$ \\
\hline Fluency & Sentence & 3.3 & 0.8 & 4.0 & 0.8 & 5.6 & $* * *$ & 1.4 & & 2.3 & $*$ & 1.4 & & 2.5 & $*$ \\
\hline Intonation & \begin{tabular}{|l|} 
Passage \\
\end{tabular} & 2.3 & 0.7 & 3.0 & 0.6 & 5.2 & \begin{tabular}{|l|l|}
$* * * *$ \\
\end{tabular} & 2.0 & $*$ & 1.9 & + & 1.3 & & 2.6 & $* *$ \\
\hline Total Impression & Total & 3.0 & 0.9 & 3.6 & 0.6 & 4.7 & $* * *$ & 1.4 & & 1.9 & + & 1.4 & & 2.4 & $*$ \\
\hline Sense Reading & Sentence & 2.6 & 0.8 & 3.3 & 0.6 & 4.6 & **** & 1.7 & + & 2.3 & * & 1.1 & & 1.9 & + \\
\hline Stress & Sentence & 3.1 & 0.8 & 3.8 & 0.5 & 4.6 & $* * *$ & 1.1 & & 1.9 & + & 1.3 & & 2.5 & $*$ \\
\hline \multirow{2}{*}{ Sentence Stress } & Passage & 2.4 & 0.6 & 3.0 & 0.6 & 4.6 & $* * *$ & 1.7 & + & 1.6 & & 1.3 & & 2.3 & $*$ \\
\hline & Sentence & 2.6 & 0.7 & 3.2 & 0.6 & 4.3 & $* * *$ & 1.4 & & 1.5 & & 1.7 & + & 2.3 & $*$ \\
\hline Stress & Passage & 2.9 & 0.8 & 3.4 & 0.6 & 4.3 & $* * *$ & 0.0 & & 2.3 & $*$ & 1.7 & + & 2.3 & $*$ \\
\hline Intonation & Sentence & 2.6 & 0.8 & 3.2 & 0.6 & 4.0 & $* * *$ & 1.4 & & 1.5 & & 1.7 & + & 2.1 & $*$ \\
\hline Pronunciation & \begin{tabular}{|l|} 
Sentence \\
\end{tabular} & 3.4 & 0.6 & 3.8 & 0.6 & 3.9 & $* * *$ & 0.0 & & 2.2 & $*$ & 0.0 & & 2.6 & $* *$ \\
\hline Message & \begin{tabular}{|l|} 
Passage \\
\end{tabular} & 2.5 & 0.9 & 3.1 & 0.7 & 3.8 & $* * *$ & 1.3 & & 1.6 & & 1.6 & & 1.9 & + \\
\hline Fluency & Passage & 3.0 & 1.0 & 3.6 & 0.7 & 3.6 & $* * *$ & 1.4 & & 1.3 & & 0.8 & & 2.3 & $*$ \\
\hline Attitude & \begin{tabular}{|l|} 
Passage \\
\end{tabular} & 3.5 & 0.8 & 3.9 & 0.6 & 3.0 & $* *$ & 0.0 & & 2.0 & $*$ & 1.4 & & 1.9 & + \\
\hline Sense Reading & \begin{tabular}{|l|} 
Passage \\
\end{tabular} & 2.7 & 0.9 & 3.1 & 0.7 & 2.8 & $* *$ & 1.0 & & 1.1 & & 1.0 & & 1.9 & + \\
\hline Volume & Word & 4.2 & 0.7 & 3.9 & 0.7 & 2.1 & $*$ & 1.0 & & 1.0 & & 1.1 & & 1.0 & \\
\hline Pronunciation & Passage & 3.0 & 0.8 & 3.2 & 0.5 & 1.8 & + & 0.4 & & 1.0 & & 1.7 & + & 1.7 & + \\
\hline Volume & \begin{tabular}{|l|} 
Passage \\
\end{tabular} & 3.7 & 0.8 & 3.9 & 0.6 & 1.3 & & 1.4 & & 0.3 & & 0.4 & & 1.6 & \\
\hline \multirow{2}{*}{ Attitude } & Word & 4.0 & 0.7 & 3.8 & 0.6 & 1.2 & & 1.3 & & 0.6 & & 0.8 & & 0.6 & \\
\hline & \begin{tabular}{|l|} 
Sentence \\
\end{tabular} & 3.7 & 0.8 & 3.8 & 0.6 & 0.9 & & 1.4 & & 2.2 & $*$ & 0.0 & & 0.0 & \\
\hline Pronunciation & Word & 3.8 & 0.6 & 3.9 & 0.4 & 0.6 & & 0.0 & & 1.0 & & 0.0 & & 0.0 & \\
\hline Volume & \begin{tabular}{|l|} 
Sentence \\
\end{tabular} & 3.9 & 0.7 & 3.9 & 0.7 & 0.3 & & 1.0 & & 1.0 & & 0.6 & & 1.0 & \\
\hline Stress & Word & 3.8 & 0.6 & 3.8 & 0.4 & 0.2 & & 1.0 & & 1.0 & & 0.0 & & 0.4 & \\
\hline
\end{tabular}


Table 5. The Factor Loading of the Oral Reading Criteria after Varimax Rotation (Experiment 1)

\begin{tabular}{|c|c|c|c|c|c|}
\hline \multirow{2}{*}{ Criteria } & \multirow{2}{*}{ Level } & \multicolumn{4}{|c|}{ Factor } \\
\hline & & 1 & 2 & 3 & 4 \\
\hline Fluency & \multirow{5}{*}{ Passage } & 0.813 & 0.188 & 0.137 & 0.069 \\
\hline Sense Reading & & 0.753 & 0.173 & -0.199 & 0.141 \\
\hline Message & & 0.675 & -0.030 & 0.050 & 0.129 \\
\hline Sentence Stress & & 0.674 & -0.011 & 0.344 & -0.132 \\
\hline Intonation & & 0.652 & -0.038 & 0.411 & -0.115 \\
\hline Total Impression & Total & 0.516 & 0.434 & 0.241 & 0.222 \\
\hline Liaison & \multirow{3}{*}{ Passage } & 0.506 & -0.109 & 0.168 & -0.132 \\
\hline Stress & & 0.476 & 0.157 & 0.413 & -0.137 \\
\hline Pronunciation & & 0.445 & 0.061 & 0.289 & -0.225 \\
\hline Volume & \multirow{2}{*}{ Passage } & 0.283 & 0.790 & 0.040 & -0.075 \\
\hline Attitude & & 0.224 & 0.759 & 0.145 & -0.075 \\
\hline Attitude & Word & -0.422 & 0.758 & -0.178 & 0.306 \\
\hline \begin{tabular}{|l} 
Volume \\
\end{tabular} & Sentence & 0.021 & 0.735 & -0.150 & 0.075 \\
\hline Volume & Word & -0.242 & 0.686 & -0.237 & 0.345 \\
\hline Attitude & \multirow{2}{*}{ Sentence } & -0.136 & 0.670 & 0.172 & 0.141 \\
\hline Pronunciation & & 0.246 & 0.500 & 0.128 & 0.065 \\
\hline Intonation & \multirow{6}{*}{ Sentence } & 0.102 & -0.026 & 0.952 & 0.002 \\
\hline Sentence Stress & & 0.077 & -0.018 & 0.918 & -0.066 \\
\hline Liaison & & 0.484 & -0.049 & 0.569 & 0.161 \\
\hline Sense Reading & & 0.132 & 0.111 & 0.526 & 0.523 \\
\hline Fluency & & 0.442 & 0.025 & 0.500 & 0.375 \\
\hline Stress & & 0.333 & 0.115 & 0.472 & 0.048 \\
\hline Pronunciation & \multirow{2}{*}{ Word } & -0.030 & 0.203 & -0.039 & 0.942 \\
\hline Stress & & -0.019 & 0.114 & 0.034 & 0.866 \\
\hline \multicolumn{2}{|c|}{ Contribution ratio (\%) } & 18.9 & 16.1 & 15.4 & 10.6 \\
\hline
\end{tabular}

In order to investigate differences among the personality groups on the development of oral reading skill, the authors conducted One-way Factorial ANOVA using the degree of development in each category of oral reading criteria which was calculated through subtracting the pre-score from the post-score for each personality group. The result showed that there was no significant difference among personality groups $(\mathrm{F}(3.86)=.639)$.

The authors conducted the discriminant analysis in order to figure out the key factors which contribute to the classification of personality group in terms of oral reading skill and important factors among them for each personality group. The result showed that 'Attitude' and 'Stress' at a word level, 'Fluency' and 'Volume' at a passage level and 'Sense Reading' at a sentence level were the key factors for the classification of personality groups as shown in Table 6. The first eigenvalue was 113.716, which meant that it explained $92.4 \%$ of the variation in the data.

As shown in Table 7, all the key factors for the classification of personality groups mentioned above were the important factors for Group 2(Cluster 2 in Table 7). The important factor for Group 4 (Cluster 4 in Table 7) was 'Sentence Stress.'

In Control Group, there was no significant development between the scores of pre and post performance tests. The authors compared the scores of the Experimental Group with those of the Control Group as for 24 categories at the pre oral reading performance tests. The result showed that there were differences between the two groups in seven categories at the significance level of $0.1 \%$, in three categories at the significance level of $1 \%$ and in eight categories at the significance level of $5 \%$. There was a tendency of difference in two categories at the significance level of $10 \%$. 
Table 6. The Standardized Canonical Discriminant Function Coefficients

\begin{tabular}{|c|c|c|c|c|}
\hline \multirow{2}{*}{ Criteria } & \multirow{2}{*}{ Level } & \multicolumn{3}{|c|}{ Function } \\
\hline & & 1 & 2 & 3 \\
\hline Attitude & \multirow{2}{*}{ Word } & 19.187 & 2.575 & -0.938 \\
\hline Stress & & 15.369 & 5.179 & 1.747 \\
\hline Fluency & \multirow{2}{*}{ Passage } & 6.816 & 2.736 & -1.789 \\
\hline Volume & & 6.697 & -5.519 & -0.028 \\
\hline Sense Reading & \multirow{3}{*}{ Sentence } & 5.493 & 0.069 & -0.836 \\
\hline \begin{tabular}{|l|} 
Sentence Stress \\
\end{tabular} & & 3.979 & -9.533 & -1.005 \\
\hline Attitude & & 3.903 & -5.152 & 0.125 \\
\hline Stress & Passage & 3.280 & -0.509 & 0.004 \\
\hline Pronunciation & Sentence & 2.627 & -0.685 & -0.609 \\
\hline Liaison & \multirow{3}{*}{ Passage } & 2.585 & 0.831 & 0.769 \\
\hline Message & & 2.553 & 2.333 & 0.780 \\
\hline Intonation & & 2.347 & -2.542 & 0.731 \\
\hline Stress & Sentence & 0.419 & -2.484 & -0.065 \\
\hline Sentence Stress & Passage & -0.084 & 0.503 & -1.315 \\
\hline Fluency & \multirow{2}{*}{ Sentence } & -1.718 & 1.415 & -0.242 \\
\hline Liaison & & -2.338 & -1.755 & -0.400 \\
\hline Pronunciation & \multirow{2}{*}{ Passage } & -3.276 & -2.061 & 1.319 \\
\hline Sense Reading & & -4.248 & -0.637 & 0.652 \\
\hline Volume & \multirow{2}{*}{ Sentence } & -5.249 & 1.595 & -0.560 \\
\hline Intonation & & -7.622 & 13.896 & 1.856 \\
\hline Volume & Word & -10.769 & 2.000 & 0.695 \\
\hline Attitude & Passage & -12.231 & 7.611 & 1.168 \\
\hline Pronunciation & Word & -19.250 & -8.487 & -0.466 \\
\hline
\end{tabular}

Table 7. The Classification Function Coefficients by Fisher's linear Discriminant Functions

\begin{tabular}{|c|c|c|c|c|c|}
\hline \multirow{2}{*}{ Criteria } & \multirow{2}{*}{ Level } & \multicolumn{4}{|c|}{ cluster } \\
\hline & & 1 & 2 & 3 & 4 \\
\hline Pronunciation & \multirow{4}{*}{ Word } & 412.949 & -322.879 & 113.252 & -209.824 \\
\hline Stress & & -293.061 & 248.699 & -74.817 & 152.072 \\
\hline Attitude & & -321.771 & 338.989 & -93.579 & 201.279 \\
\hline \begin{tabular}{|l|} 
Volume \\
\end{tabular} & & 171.234 & -223.673 & 56.661 & -117.729 \\
\hline Pronunciation & \multirow{9}{*}{ Sentence } & -55.140 & 80.452 & -20.932 & 43.245 \\
\hline Stress & & 6.506 & 21.090 & -1.859 & 2.994 \\
\hline Sentence Stress & & 21.063 & 162.763 & 8.463 & 68.843 \\
\hline Intonation & & 8.912 & -256.961 & 8.771 & -107.608 \\
\hline Fluency & & 21.813 & -45.019 & 7.240 & -18.602 \\
\hline Liaison & & 81.472 & -25.157 & 30.248 & -14.241 \\
\hline Sense Reading & & -89.502 & 87.478 & -34.698 & 47.425 \\
\hline Attitude & & -53.071 & 138.003 & -29.565 & 46.153 \\
\hline Volume & & 114.450 & -130.863 & 41.731 & -57.663 \\
\hline Pronunciation & \multirow{10}{*}{ Passage } & 82.646 & -58.547 & 29.540 & -45.538 \\
\hline Stress & & -53.063 & 69.231 & -15.760 & 36.742 \\
\hline \begin{tabular}{|l|} 
Sentence Stress \\
\end{tabular} & & -0.125 & -6.442 & -6.348 & 0.988 \\
\hline \begin{tabular}{|l|} 
Intonation \\
\end{tabular} & & -21.722 & 64.730 & -4.186 & 25.977 \\
\hline Fluency & & -111.382 & 98.520 & -36.166 & 68.031 \\
\hline Liaison & & -53.630 & 44.853 & -11.635 & 26.043 \\
\hline Sense Reading & & 53.301 & -67.798 & 13.050 & -43.585 \\
\hline Message & & -47.725 & 33.370 & -5.025 & 26.973 \\
\hline Attitude & & 169.121 & -301.668 & 68.250 & -137.598 \\
\hline Volume & & -71.853 & 130.519 & -32.214 & 51.692 \\
\hline \multicolumn{2}{|c|}{ Constant } & -93.313 & -110.769 & -22.790 & -40.777 \\
\hline
\end{tabular}




\subsubsection{Comparative Examination on the Effects of Experiment on the Oral Reading Skill}

In Experiment 1, the most categories of oral reading performance were improved significantly. However, as there were significant differences between the Experimental Group and the Control Group in the most categories at the pre oral reading performance tests, the authors examined the effects of blended instruction on the oral reading skill in Experiment 2 after setting the Control Group which was almost equal to the Experimental Group in the oral reading skill.

The authors compared the scores of the pre and post oral reading performance tests in Experiment 2. As shown in Table 8, the result of the t-tests shows that all the categories of the oral reading performance were improved at the significance level of $0.1 \%$ in the Experimental Group. On the other hand, only the category of 'Pronunciation' at a word level was improved at the significance level of $5 \%$ and there was a tendency of development in 'Total impression' in the Control Group.

The authors also compared the scores of the Experimental Group with those of the Control Group as for 25 categories at the pre oral reading performance tests. The result showed that there was no difference between the two groups in 22 categories out of 25 except the categories of 'Volume' at word, sentence and passage level which had differences at the significance level of $5 \%$ to $1 \%$.

After the degree of development in each category of oral reading criteria in Table 8 was calculated through subtracting the pre-score from the post-score, factor analysis was conducted for all the 25 categories using unweighted least squares method and varimax rotation in order to clarify the factors which contributed to the development. Four factors were extracted as shown in Table 9. The contribution ratio was $72.4 \%$ in total.

Table 8. The Improvement of the Oral Reading Performance in the Experimental Group and the Control Group

\begin{tabular}{|c|c|c|c|c|c|c|c|c|c|c|c|c|c|}
\hline \multirow{3}{*}{ Criteria } & \multirow{3}{*}{ Level } & \multicolumn{6}{|c|}{$\begin{array}{c}\text { Experimantal } \\
(\mathrm{n}=81)\end{array}$} & \multicolumn{6}{|c|}{$\begin{array}{l}\text { Control } \\
(\mathrm{n}=59)\end{array}$} \\
\hline & & \multicolumn{2}{|c|}{ Pre-test } & \multicolumn{2}{|c|}{ Post-test } & \multicolumn{2}{|c|}{ t-Test } & \multicolumn{2}{|c|}{ Pre-test } & \multicolumn{2}{|c|}{ Post-test } & \multicolumn{2}{|c|}{ t-Test } \\
\hline & & mean & SD & mean & SD & $\begin{array}{l}\text { Value } \\
\text { of } t\end{array}$ & $\begin{array}{c}\text { Sig. } \\
\text { level }\end{array}$ & mean & $\mathrm{SD}$ & mean & SD & $\begin{array}{c}\text { Value } \\
\text { of } t\end{array}$ & $\begin{array}{c}\text { Sig. } \\
\text { level }\end{array}$ \\
\hline Stress & Word & 2.9 & 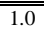 & 3.7 & 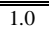 & 99.0 & "***** & 3.1 & 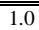 & 3.2 & 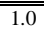 & 0.7 & \\
\hline Intonation & Word & 2.9 & 1.0 & 3.7 & 1.0 & 8.7 & $* * *$ & 3.1 & 1.0 & 3.2 & 1.0 & 1.3 & \\
\hline Stress & Passage & 2.4 & 1.0 & 3.0 & 1.2 & 8.3 & $* * * *$ & 2.6 & 0.9 & 2.6 & 0.9 & \begin{tabular}{|l|l|}
0.7 \\
\end{tabular} & \\
\hline Fluency & Passage & 2.6 & 1.1 & 3.1 & 1.3 & 8.1 & ***** & 2.7 & 1.1 & 2.9 & 1.1 & 1.5 & \\
\hline Message & Passage & 2.4 & 1.0 & 3.0 & 1.2 & 7.7 & $* * *$ & 2.7 & 1.0 & 2.7 & 1.0 & 0.0 & \\
\hline Total Impression & Total & 2.7 & 1.1 & 3.2 & 1.3 & 7.5 & $* * *$ & 2.8 & 1.0 & 3.0 & 1.0 & 1.8 & + \\
\hline \begin{tabular}{|l|} 
Pronunciation \\
\end{tabular} & Word & 3.1 & 1.1 & 3.8 & 1.0 & 7.3 & $* * * *$ & 3.2 & 1.1 & 3.4 & 1.0 & 2.1 & $*$ \\
\hline \multirow{2}{*}{ Intonation } & Sentence & 2.8 & 1.1 & 3.3 & 1.3 & 7.2 & **** & 3.0 & 0.9 & 2.9 & 1.0 & 0.4 & \\
\hline & Passage & 2.6 & 1.1 & 3.1 & 1.3 & 7.2 & ***** & 2.6 & 1.0 & 2.7 & 1.0 & 1.2 & \\
\hline Liaison & Passage & 2.6 & 1.1 & 3.1 & 1.3 & 7.2 & $* * *$ & 2.7 & 1.1 & 2.7 & 1.1 & 0.5 & \\
\hline Stress & Sentence & 2.6 & 1.0 & 3.2 & 1.2 & 6.9 & $* * * *$ & 2.9 & 0.9 & 2.8 & 0.9 & 1.0 & \\
\hline \begin{tabular}{|l|} 
Sense Reading \\
\end{tabular} & Passage & 2.5 & 1.0 & 3.0 & 1.2 & 6.9 & $* * * *$ & 2.7 & 1.0 & 2.6 & 0.9 & 0.4 & \\
\hline Pronunciation & Sentence & 2.7 & 0.9 & 3.2 & 1.2 & 6.8 & $* * *$ & 2.9 & 0.9 & 3.0 & 1.0 & 0.2 & \\
\hline \multirow{2}{*}{ Sentence Stress } & Passage & 2.4 & 1.0 & 2.9 & 1.1 & 6.8 & $* * * *$ & 2.6 & 1.0 & 2.6 & 0.9 & \begin{tabular}{|l|l|}
0.0 \\
\end{tabular} & \\
\hline & Sentence & 2.6 & 1.0 & 3.2 & 1.2 & 6.7 & $* * *$ & 2.9 & 0.9 & 2.8 & 0.9 & 1.0 & \\
\hline Volume & Passage & 2.9 & 1.2 & 3.4 & 1.3 & 6.7 & ***** & 3.3 & 1.2 & 3.2 & 1.0 & 0.5 & \\
\hline Fluency & Sentence & 2.8 & 1.1 & 3.4 & 1.3 & 6.6 & **** & 3.1 & 1.0 & 3.0 & 1.1 & 0.5 & \\
\hline \begin{tabular}{|l|} 
Sense Reading \\
\end{tabular} & Sentence & 2.7 & 1.0 & 3.2 & 1.2 & 6.0 & ***** & 2.9 & 0.9 & 2.8 & 0.9 & 1.1 & \\
\hline Pronunciation & Passage & 2.5 & 0.9 & 3.0 & 1.2 & 5.8 & **** & 2.6 & 0.9 & 2.7 & 0.9 & 0.5 & \\
\hline \begin{tabular}{|l|} 
Attitude \\
\end{tabular} & Passage & 2.9 & 1.2 & 3.3 & 1.3 & 5.7 & ***** & 3.1 & 1.0 & 3.2 & 1.0 & 1.1 & \\
\hline \multirow{2}{*}{ Volume } & Word & 3.2 & 1.1 & 3.8 & 1.0 & 5.6 & ****** & 3.6 & 1.1 & 3.5 & 1.0 & 1.5 & \\
\hline & Sentence & 3.0 & 1.1 & 3.5 & 1.3 & 5.4 & ***** & 3.5 & 1.1 & 3.3 & 0.9 & 1.6 & \\
\hline \begin{tabular}{|l|} 
Attitude \\
\end{tabular} & Word & 3.3 & 1.0 & 3.8 & 1.0 & 5.2 & ***** & 3.3 & 1.0 & 3.4 & 1.0 & 1.1 & \\
\hline Liaison & Sentence & 2.9 & 1.1 & 3.2 & 1.2 & 4.7 & ***** & 3.0 & 1.0 & 2.9 & 1.0 & 1.0 & \\
\hline \begin{tabular}{|l|} 
Attitude \\
\end{tabular} & Sentence & 3.1 & 1.1 & 3.4 & 1.3 & 4.1 & ***** & 3.2 & 0.9 & 3.2 & 0.9 & 0.2 & \\
\hline
\end{tabular}


Table 9. The Factor Loading of the Oral Reading Criteria after Varimax Rotation (Experiment 2)

\begin{tabular}{|c|c|c|c|c|c|}
\hline \multirow{2}{*}{ Criteria } & \multirow{2}{*}{ Level } & \multicolumn{4}{|c|}{ Factor } \\
\hline & & 1 & 2 & 3 & 4 \\
\hline Stress & \multirow{8}{*}{ Passage } & 0.841 & 0.301 & 0.152 & 0.083 \\
\hline Intonation & & 0.794 & 0.118 & 0.158 & 0.244 \\
\hline Liaison & & 0.782 & 0.160 & 0.088 & 0.208 \\
\hline Sense Reading & & 0.768 & 0.367 & 0.076 & 0.096 \\
\hline Message & & 0.757 & 0.210 & 0.145 & 0.120 \\
\hline Sentence Stress & & 0.756 & 0.193 & 0.055 & 0.109 \\
\hline Fluency & & 0.687 & 0.226 & 0.071 & 0.280 \\
\hline Pronunciation & & 0.371 & 0.355 & 0.063 & 0.286 \\
\hline Stress & \multirow{7}{*}{ Sentence } & 0.400 & 0.786 & 0.285 & 0.268 \\
\hline Sentence Stress & & 0.383 & 0.745 & 0.293 & 0.245 \\
\hline Sense Reading & & 0.348 & 0.719 & 0.298 & 0.286 \\
\hline Pronunciation & & 0.265 & 0.621 & 0.107 & 0.498 \\
\hline Intonation & & 0.387 & 0.612 & 0.221 & 0.453 \\
\hline Liaison & & 0.323 & 0.605 & 0.139 & 0.446 \\
\hline Fluency & & 0.383 & 0.585 & 0.196 & 0.461 \\
\hline Stress & \multirow{5}{*}{ Word } & 0.144 & 0.228 & 0.909 & 0.074 \\
\hline Intonation & & 0.134 & 0.263 & 0.883 & 0.059 \\
\hline Attitude & & 0.114 & 0.102 & 0.834 & 0.184 \\
\hline Pronunciation & & 0.102 & 0.279 & 0.823 & 0.138 \\
\hline Volume & & 0.083 & -0.073 & 0.751 & 0.395 \\
\hline \multirow{2}{*}{ Volume } & \begin{tabular}{|l|} 
Sentence \\
\end{tabular} & 0.135 & 0.312 & 0.221 & 0.827 \\
\hline & \begin{tabular}{|l|} 
Passage \\
\end{tabular} & 0.139 & 0.188 & 0.143 & 0.755 \\
\hline \multirow{2}{*}{ Attitude } & Sentence & 0.186 & 0.400 & 0.265 & 0.639 \\
\hline & \begin{tabular}{|l|} 
Passage \\
\end{tabular} & 0.364 & 0.250 & 0.127 & 0.568 \\
\hline Total Impression & Total & 0.431 & 0.372 & 0.218 & 0.518 \\
\hline \multicolumn{2}{|c|}{ Contribution ratio (\%) } & 22.6 & 17.6 & 16.9 & 15.4 \\
\hline
\end{tabular}

Factor 1 was interpreted as "Pronunciation of Passage" because it related to the categories of 'Passage level.' In the same way, Factor 2 was interpreted as "Pronunciation of Sentence". Factor 3 was interpreted as "Pronunciation of Word". Factor 4 was interpreted as "Attitude and Volume".

\subsubsection{The Development of the Oral Reading Skill in each Personality Group and the Related Factors}

In terms of educational effects on each personality group, the authors compared the scores of pre and post oral reading performance tests in each personality group of the Experimental Group. As shown in Table 10, the result of the t-test shows that the oral reading skill of the Group $4(\mathrm{Cl} 4$ in Table 10) developed significantly in all the categories. The group whose oral reading skill developed significantly in the second most categories of all the groups is the Group 2 ( $\mathrm{Cl} 2$ in Table 10).

In order to figure out differences among the personality groups on the development of oral reading skill, One-way Factorial ANOVA was conducted after the degree of development in each category of oral reading criteria was calculated through subtracting the pre-score from the post-score for each personality group in the same way as Experiment 1 . The result showed that there was significant differences among personality groups $(\mathrm{F}(3,96)=14.8, \mathrm{p}<.001)$.

As post-hoc tests, Bonferroni multiple comparisons of means were conducted. As shown in Table 11, there were significant differences between Group 1 (Cluster 1 in Table 11) and Group 2 (Cluster 2 in Table 11) at significance level of $0.1 \%$ and between Group 1 and Group 4 (Cluster 4 in Table 11) at significance level of 1\%. There were also significant differences between Group 3 (Cluster 3 in Table 11) and Group 2 and between Group 3 and Group 4 at significance level of $0.1 \%$. There was no significant difference 
between Group1 $(\mathrm{m}=0.4)$ and Group $3(\mathrm{~m}=0.4)$ and between Group $2(\mathrm{~m}=0.6)$ and Group $4(\mathrm{~m}=0.6)$, where $\mathrm{m}$ stands for means.

In order to figure out key factors which contribute to the classification of the personality group in terms of oral reading skill and important factors among them for each personality group, the authors conducted the discriminant analysis. The result showed that 'Sense Reading' at a sentence level, 'Intonation' at all the levels and 'Liaison' at a sentence level were the key factors for the classification of personality groups as shown in Table 12. The first eigenvalue was 0.892 , which meant that it explained $54.8 \%$ of the variation in the data.

As shown in Table 13, the important factor for Group 4 (Cluster 4 in Table 13) was 'Sense Reading' at a sentence level. The one for Group 2 (Cluster 2 in Table 13) was 'Intonation' at all the levels. The one for Group 1 (Cluster 1 in Table 13) was 'Liaison' at the sentence level.

Table 10. The Improvement of the Oral Reading Performance in each Personality Group

\begin{tabular}{|c|c|c|c|c|c|c|c|c|c|c|c|}
\hline \multirow{2}{*}{ Criteria } & \multirow{2}{*}{ Level } & \multicolumn{2}{|c|}{$\begin{array}{c}\text { Experoimantal } \\
\quad(\mathrm{n}=81)\end{array}$} & \multicolumn{2}{|c|}{$\begin{array}{c}\mathrm{Cl} 1 \\
(\mathrm{n}=21)\end{array}$} & \multicolumn{2}{|c|}{$\begin{array}{c}\mathrm{Cl} 2 \\
(\mathrm{n}=18)\end{array}$} & \multicolumn{2}{|c|}{$\begin{array}{c}\mathrm{Cl} 3 \\
(\mathrm{n}=16)\end{array}$} & \multicolumn{2}{|c|}{$\begin{array}{c}\mathrm{Cl} 4 \\
(\mathrm{n}=23)\end{array}$} \\
\hline & & $\begin{array}{c}\begin{array}{c}\text { Value } \\
\text { of } \mathrm{t}\end{array} \\
\end{array}$ & $\begin{array}{c}\text { Sig. } \\
\text { level } \\
\end{array}$ & $\begin{array}{c}\text { Value } \\
\text { of } \mathrm{t}\end{array}$ & \begin{tabular}{|c|} 
Sig. \\
level \\
\end{tabular} & $\begin{array}{c}\text { Value } \\
\text { of } \mathrm{t}\end{array}$ & \begin{tabular}{|c|} 
Sig. \\
level \\
\end{tabular} & $\begin{array}{c}\text { Value } \\
\text { of } \mathrm{t}\end{array}$ & \begin{tabular}{|c|} 
Sig. \\
level \\
\end{tabular} & \begin{tabular}{|c|}
$\begin{array}{c}\text { Value } \\
\text { of } t\end{array}$ \\
\end{tabular} & \begin{tabular}{|c|} 
Sig. \\
level \\
\end{tabular} \\
\hline Stress & Word & 9.0 & **** & 4.2 & **** & 5.1 & **** & 3.5 & $* *$ & \begin{tabular}{|l|}
4.9 \\
\end{tabular} & **** \\
\hline Intonation & Word & 8.7 & **** & 3.9 & $* * *$ & 5.0 & **** & 3.4 & *** & 4.5 & $* * *$ \\
\hline Stress & Passage & 8.3 & **** & 4.0 & **** & 6.0 & **** & 3.4 & *** & 3.4 & ** \\
\hline Fluency & Passage & 8.1 & **** & 3.2 & *** & 3.7 & ** & 3.9 & **** & 4.8 & $* * *$ \\
\hline Message & Passage & 7.7 & **** & 3.2 & *** & 5.3 & *** & 2.8 & $*$ & 3.8 & *** \\
\hline Total Impression & Total & 7.5 & **** & 3.2 & *** & 5.2 & **** & 1.6 & & 5.5 & **** \\
\hline Pronunciation & Word & 7.3 & **** & 2.6 & $*$ & 4.2 & **** & 2.4 & $*$ & 5.1 & $* * *$ \\
\hline \multirow{2}{*}{ Intonation } & Sentence & 7.2 & **** & 2.9 & *** & 5.0 & $* * *$ & 1.8 & + & 4.4 & $* * *$ \\
\hline & Passage & 7.2 & **** & 3.2 & *** & 4.8 & **** & 2.1 & + & 4.0 & *** \\
\hline Liaison & Passage & 7.2 & **** & 3.3 & $* *$ & 3.1 & $* *$ & 3.2 & $* *$ & 4.0 & $* * *$ \\
\hline \begin{tabular}{|l|} 
Stress \\
\end{tabular} & Sentence & 6.9 & **** & 3.0 & *** & 5.7 & **** & 1.0 & & 4.0 & **** \\
\hline Sense Reading & Passage & 6.9 & $* * *$ & 3.3 & *** & \begin{tabular}{|l|}
4.1 \\
\end{tabular} & *** & 2.1 & + & 4.2 & *** \\
\hline \begin{tabular}{|l|} 
Pronunciation \\
\end{tabular} & Sentence & 6.8 & ***** & 2.8 & * & 9.2 & **** & 1.2 & & \begin{tabular}{|l|}
4.5 \\
\end{tabular} & *** \\
\hline \multirow{2}{*}{ Sentence Stress } & Passage & 6.8 & **** & 2.0 & + & 4.8 & **** & 3.0 & $* *$ & 3.4 & ** \\
\hline & Sentence & 6.7 & **** & 2.8 & $*$ & 5.0 & *** & 1.0 & & 4.4 & *** \\
\hline Volume & Passage & 6.7 & ***** & 2.3 & $*$ & 6.6 & **** & 1.5 & & 5.3 & $* * *$ \\
\hline Fluency & Sentence & 6.6 & **** & 2.4 & $*$ & 5.2 & **** & 1.8 & + & 4.4 & $* * *$ \\
\hline Sense Reading & Sentence & 6.0 & $* * *$ & 2.4 & $*$ & 5.3 & *** & 0.0 & & 4.2 & *** \\
\hline Pronunciation & Passage & 5.8 & **** & 2.9 & *** & \begin{tabular}{|l}
4.6 \\
\end{tabular} & *** & 1.3 & & \begin{tabular}{|l|}
3.1 \\
\end{tabular} & ** \\
\hline Attitude & Passage & 5.7 & **** & 3.9 & **** & \begin{tabular}{|l|}
3.8 \\
\end{tabular} & **** & \begin{tabular}{|l|}
0.3 \\
\end{tabular} & & \begin{tabular}{|l|}
3.9 \\
\end{tabular} & *** \\
\hline \multirow{2}{*}{ Volume } & Word & 5.6 & **** & 1.8 & + & 1.8 & + & 2.7 & $*$ & \begin{tabular}{|l|}
4.4 \\
\end{tabular} & $* * *$ \\
\hline & Sentence & 5.4 & **** & 1.5 & & 5.3 & *** & 1.2 & & \begin{tabular}{|l|}
4.0 \\
\end{tabular} & *** \\
\hline \begin{tabular}{|l|l} 
Attitude \\
\end{tabular} & Word & 5.2 & **** & 2.0 & + & 3.1 & *** & 1.5 & & \begin{tabular}{|l|}
3.4 \\
\end{tabular} & ** \\
\hline Liaison & Sentence & 4.7 & **** & 2.1 & $*$ & 2.9 & *** & 0.3 & & \begin{tabular}{|l}
3.7 \\
\end{tabular} & *** \\
\hline Attitude & Sentence & 4.1 & *** & 1.5 & & 4.1 & *** & 0.0 & & \begin{tabular}{|l|}
3.8 \\
\end{tabular} & *** \\
\hline
\end{tabular}

Table 11. The Bonferroni Multiple Comparisons of Means

\begin{tabular}{|c|c|c|c|c|c|}
\hline (I)Cluster & (J)Cluster & \begin{tabular}{c|} 
Mean \\
Difference \\
(I-J)
\end{tabular} & Std. Error & \multicolumn{2}{|c|}{ Sig. } \\
\hline \multirow[t]{3}{*}{1} & 2 & -.218 & .048 & .000 & **** \\
\hline & 3 & .050 & .048 & 1.000 & \\
\hline & 4 & -.175 & .048 & .003 & $* *$ \\
\hline \multirow[t]{3}{*}{2} & 1 & .218 & .048 & .000 & **** \\
\hline & 3 & .267 & .048 & .000 & **** \\
\hline & 4 & .042 & .048 & 1.000 & \\
\hline \multirow[t]{3}{*}{3} & 1 & -.050 & .048 & 1.000 & \\
\hline & 2 & -.267 & .048 & .000 & **** \\
\hline & 4 & -.225 & .048 & .000 & **** \\
\hline \multirow[t]{3}{*}{4} & 1 & .175 & .048 & .003 & *** \\
\hline & 2 & -.042 & .048 & 1.000 & \\
\hline & 3 & .225 & .048 & .000 & **** \\
\hline
\end{tabular}


Table 12. The Standardized Canonical Discriminant Function Coefficients

\begin{tabular}{|l|c|c|c|c|}
\hline \multirow{2}{*}{ Criteria } & \multirow{2}{*}{ Level } & \multicolumn{3}{|c|}{ Function } \\
\cline { 3 - 5 } & & 1 & 2 & 3 \\
\hline Sense Reading & \multirow{3}{*}{ Sentence } & 1.267 & 0.315 & 1.143 \\
\cline { 3 - 5 } & & 1.249 & 0.203 & -0.117 \\
\cline { 3 - 5 } Intonation & 0.977 & -0.924 & -0.441 \\
\hline Liaison & Word & 0.896 & 0.933 & 0.068 \\
\cline { 2 - 5 } Intonation & Passage & 0.739 & -0.180 & 0.129 \\
\hline \multirow{3}{*}{ Attitude } & Passage & 0.418 & 0.209 & -0.016 \\
\cline { 2 - 5 } & Sentence & 0.381 & -0.434 & 0.393 \\
\cline { 2 - 5 } & Word & 0.284 & 0.308 & -0.804 \\
\hline Total Impression & Total & 0.226 & 0.751 & 0.581 \\
\hline Sense Reading & Passage & 0.190 & -0.630 & -0.189 \\
\hline Stress & Passage & 0.083 & -0.945 & 0.026 \\
\hline Volume & Passage & 0.080 & -0.322 & -0.524 \\
\hline Sentence Stress & Sentence & 0.060 & 0.101 & -2.110 \\
\hline \multirow{2}{*}{ Pronunciation } & Sentence & -0.033 & 0.337 & -0.144 \\
\cline { 2 - 5 } & Word & -0.259 & -0.225 & 0.149 \\
\hline Liaison & Passage & -0.287 & -0.421 & -0.061 \\
\hline Sentence Stress & Passage & -0.311 & 0.724 & 0.068 \\
\hline Pronunciation & Passage & -0.342 & -0.132 & -0.236 \\
\hline Message & Passage & -0.352 & 0.719 & -0.536 \\
\hline Fluency & Passage & -0.451 & 1.025 & 0.347 \\
\hline \multirow{2}{*}{ Volume } & Sentence & -0.508 & 0.459 & -0.289 \\
\cline { 2 - 5 } & Word & -0.677 & -0.394 & 1.210 \\
\hline Fluency & Sentence & -0.758 & -0.749 & -0.159 \\
\hline \multirow{2}{*}{ Stress } & Word & -0.791 & -0.603 & -0.434 \\
\cline { 2 - 5 } & Sentence & -1.907 & 0.213 & 1.973 \\
\hline & & & & \\
& & & \\
\hline
\end{tabular}

Table 13. The Classification Function Coefficients by Fisher's linear Discriminant Functions

\begin{tabular}{|c|c|c|c|c|c|}
\hline \multirow{2}{*}{ Criteria } & \multirow{2}{*}{ Level } & \multicolumn{4}{|c|}{ Cluster } \\
\hline & & 1 & 2 & 3 & 4 \\
\hline Pronunciation & \multirow{5}{*}{ Word } & 0.031 & -0.699 & 0.370 & 0.015 \\
\hline Stress & & 1.078 & -0.772 & 1.895 & -0.008 \\
\hline Intonation & & 0.254 & 2.932 & -0.438 & 1.225 \\
\hline Attitude & & -0.161 & 0.711 & -0.597 & -0.949 \\
\hline Volume & & -0.322 & -1.552 & 0.928 & 0.849 \\
\hline Pronunciation & \multirow{9}{*}{ Sentence } & 0.000 & 0.819 & 0.631 & 0.188 \\
\hline Stress & & -2.367 & -3.346 & 3.772 & 1.059 \\
\hline Sentence Stress & & 0.522 & 0.719 & -0.111 & -2.564 \\
\hline Intonation & & 0.960 & 2.515 & -2.098 & 0.904 \\
\hline Fluency & & 0.562 & -1.777 & 1.224 & -0.415 \\
\hline Liaison & & 0.920 & -0.457 & -3.048 & -0.771 \\
\hline Sense Reading & & -0.257 & 1.817 & -3.005 & 1.880 \\
\hline Attitude & & 0.144 & -0.563 & -1.429 & 0.184 \\
\hline Volume & & -1.193 & -0.536 & 0.730 & -1.045 \\
\hline Pronunciation & \multirow{10}{*}{ Passage } & -0.211 & -0.833 & 0.407 & -0.684 \\
\hline Stress & & 0.342 & -2.049 & -1.570 & -0.793 \\
\hline Sentence Stress & & 0.276 & 2.013 & 2.627 & 1.384 \\
\hline Intonation & & -0.171 & 0.009 & -2.438 & -0.262 \\
\hline Fluency & & -0.660 & 1.794 & 2.771 & 1.325 \\
\hline Liaison & & 0.403 & -0.947 & 0.437 & -0.183 \\
\hline Sense Reading & & 1.260 & -0.352 & -0.606 & 0.073 \\
\hline Message & & -0.809 & 0.648 & 1.186 & -0.732 \\
\hline Attitude & & 1.249 & 2.282 & 0.334 & 1.466 \\
\hline Volume & & 1.012 & 0.219 & 0.051 & -0.210 \\
\hline Total Impression & Total & -0.159 & 2.197 & 0.795 & 1.797 \\
\hline \multicolumn{2}{|c|}{ Constant } & -2.680 & -4.835 & -4.280 & -3.582 \\
\hline
\end{tabular}




\subsubsection{The Effects on the Mental Aspect and the Personality Group}

The authors compared the results of pre and post surveys using the t-test. The comparison was made on the survey items in which there was no significant difference between the Experimental Group and the Control Group at the pre survey. According to the results of the comparison about the Experimental Group in Experiment 1 as shown in Table 14, three items (Items 4, 9-1 and 19) which were related to the self-confidence toward speaking in English were developed at the significance level of 5\% to $0.1 \%$. Two items (Items 9-2 and 12) which were related to the self-confidence toward listening to English were developed at the significance level of 5\%. Two items (Items 16 and 17) which were related to the collaborative learning and an item (Item 11) which was related to the selfpaced learning with WBT courseware were also developed at the significance level of $5 \%$. On the other hand, only one item (Item 9-4) which was related to self-confidence toward reading in English was developed at the significant tendency in the Control Group.

According to the results of the comparison in the Experimental Group in Experiment 2 as shown in Table 15, an item (Item 11-1) which was related to the selfconfidence toward speaking in English was developed at the significance level of $1 \%$. An item (Item 11-2) which was related to the self-confidence toward listening to English was also developed at the significance level of 1\%. Two items (Items 17 and 18) which were related to the collaborative learning and an item (Item 13) which was related to the selfpaced learning with WBT courseware were also developed at the significance level of $0.1 \%$. On the other hand, only one item (Item 15 in Table 3) which was related to the reluctance toward speaking in English was improved at the significant tendency in the Control Group.

In terms of effects on the mental aspect of each personality group, the authors compared the scores of pre and post surveys in each personality group of the Experimental Group using the Wilcoxon signed-rank test in Experiment 1 and the t-test in Experiment 2. As shown in Table 14 and Table15, the significant developments were mainly shown in the survey items of Group $2(\mathrm{Cl} 2$ in Tables 14 and 15) and Group $4(\mathrm{Cl}$ 4 in Tables 14 and 15).

Table 14. The Development of the Mental Aspect in Experiment 1 (Experimental Group)

\begin{tabular}{|c|c|c|c|c|c|c|c|c|c|c|c|c|c|c|c|}
\hline \multirow{2}{*}{ Survey Items } & \multirow{2}{*}{$\mathrm{n}$} & \multicolumn{2}{|c|}{ Pre-test } & \multicolumn{2}{|c|}{ Post-test } & \multicolumn{2}{|c|}{ t-Test } & \multicolumn{2}{|c|}{$\begin{array}{r}\mathrm{Cl} 1 \\
(\mathrm{n}=6)\end{array}$} & \multicolumn{2}{|c|}{$\begin{array}{l}\mathrm{Cl} 2 \\
(\mathrm{n}=9)\end{array}$} & \multicolumn{2}{|c|}{$\begin{array}{l}\mathrm{Cl} 3 \\
(\mathrm{n}=4)\end{array}$} & \multicolumn{2}{|c|}{$\begin{array}{c}\mathrm{Cl} 4 \\
(\mathrm{n}=10)\end{array}$} \\
\hline & & mean & SD & mean & SD & $\begin{array}{c}\text { Value } \\
\text { of } \mathrm{t}\end{array}$ & $\begin{array}{l}\text { Sig. } \\
\text { level }\end{array}$ & $\begin{array}{c}\text { Value } \\
\text { of Z }\end{array}$ & $\begin{array}{l}\text { Sig. } \\
\text { level }\end{array}$ & $\begin{array}{l}\text { Value } \\
\text { of Z }\end{array}$ & \begin{tabular}{|c|} 
Sig. \\
level
\end{tabular} & $\begin{array}{c}\text { Value } \\
\text { of Z }\end{array}$ & $\begin{array}{l}\text { Sig. } \\
\text { level }\end{array}$ & $\begin{array}{l}\text { Value } \\
\text { of Z }\end{array}$ & \begin{tabular}{|c|} 
Sig. \\
level
\end{tabular} \\
\hline 4. Being able to talk with foreigners in English & 29 & 2.7 & 0.9 & 3.2 & 0.7 & 4.0 & ***** & 1.9 & ++ & 1.6 & & 1.0 & & 2.0 & F* \\
\hline 9-1. Self-confidence toward Speaking in English & 29 & 3.0 & 1.0 & 3.2 & 0.9 & 2.0 & $*$ & 1.0 & & 1.7 & + & 0.0 & & 1.1 & \\
\hline 9-2. Self-confidence toward Listening in English & 29 & 3.3 & 1.0 & 3.7 & 0.8 & 2.6 & $*$ & 1.0 & & 0.8 & & 0.6 & & 1.9 & * \\
\hline 9-3. Self-confidence toward Writing in English & 29 & 3.4 & 0.9 & 3.9 & 0.8 & 3.1 & *** & 1.3 & & 1.9 & + & 1.0 & & 1.4 & \\
\hline 9-4. Self-confidence toward Reading in English & 29 & 3.9 & 0.9 & 4.1 & 0.6 & 1.8 & + & 1.0 & & 2.0 & $*$ & 0.0 & & 1.3 & \\
\hline $\begin{array}{l}\text { 11. Feeling able to learn at one's own pace in English } \\
\text { lessons using computers }\end{array}$ & 29 & 3.7 & 0.9 & 4.2 & 0.8 & 2.1 & $*$ & 0.7 & & 2.4 & $*$ & 0.0 & & 0.3 & \\
\hline $\begin{array}{l}\text { 12. Being able to comprehend English conversations } \\
\text { through listening to them in usual English lessons } \\
\end{array}$ & 29 & 3.8 & 0.8 & 4.1 & 0.5 & 2.3 & * & 0.4 & & 0.6 & & 1.0 & & 2.1 & $*$ \\
\hline $\begin{array}{l}\text { 16. Being fond of practicing acting a dialogue with } \\
\text { one's partner }\end{array}$ & 29 & 3.3 & 0.8 & 3.7 & 1.0 & 2.1 & $*$ & 2.1 & $*$ & 1.3 & & 1.0 & & 0.4 & \\
\hline $\begin{array}{l}\text { 17. Being eager to instruct each other in pronunciation } \\
\text { errors with one's partner }\end{array}$ & 29 & 3.3 & 0.8 & 3.7 & 0.8 & 2.4 & $*$ & 0.6 & & 2.3 & $*$ & 1.0 & & 0.3 & \\
\hline $\begin{array}{l}\text { 19. Being eager to communicate with ALT using what } \\
\text { one learned in English lessons }\end{array}$ & 29 & 3.1 & 1.1 & 3.5 & 1.0 & 2.1 & $*$ & 1.1 & & 1.7 & + & 1.0 & & 0.4 & \\
\hline
\end{tabular}


Table 15. The Development of the Mental Aspect in Experiment 2 (Experimental Group)

\begin{tabular}{|c|c|c|c|c|c|c|c|c|c|c|c|c|c|c|c|}
\hline \multirow{2}{*}{ Survey Items } & \multirow{2}{*}{$\mathrm{n}$} & \multicolumn{2}{|c|}{ Pre-test } & \multicolumn{2}{|c|}{ Post-test } & \multicolumn{2}{|c|}{ t-Test } & \multicolumn{2}{|c|}{$\begin{array}{c}\mathrm{Cl} 1 \\
(\mathrm{n}=21)\end{array}$} & \multicolumn{2}{|c|}{$\begin{array}{c}\mathrm{Cl} 2 \\
(\mathrm{n}=18)\end{array}$} & \multicolumn{2}{|c|}{$\begin{array}{c}\mathrm{Cl} 3 \\
(\mathrm{n}=16)\end{array}$} & \multicolumn{2}{|c|}{$\begin{array}{c}\mathrm{Cl} 4 \\
(\mathrm{n}=23)\end{array}$} \\
\hline & & mean & SD & mean & SD & $\begin{array}{c}\text { Value } \\
\text { of } t\end{array}$ & \begin{tabular}{|r|} 
Sig. \\
level
\end{tabular} & $\begin{array}{c}\text { Value } \\
\text { of t }\end{array}$ & \begin{tabular}{|c|c|} 
Sig. \\
level
\end{tabular} & $\begin{array}{c}\text { Value } \\
\text { of } t\end{array}$ & $\begin{array}{l}\text { Sig. } \\
\text { level }\end{array}$ & $\begin{array}{c}\text { Value } \\
\text { of } t\end{array}$ & \begin{tabular}{|r|} 
Sig. \\
level
\end{tabular} & $\begin{array}{c}\text { Value } \\
\text { of } \mathrm{t}\end{array}$ & $\begin{array}{c}\text { Sig. } \\
\text { level }\end{array}$ \\
\hline 11-1. Self-confidence toward Speaking in English & 71 & 2.3 & 1.1 & 2.5 & 1.2 & 2.7 & *** & 1.6 & & 0.3 & & 0.9 & & 2.3 & $*$ \\
\hline 11-2. Self-confidence toward Listening in English & 71 & 2.5 & 1.0 & 2.8 & 1.1 & 3.1 & *** & 2.2 & * & 3.0 & *** & 0.6 & & 0.3 & \\
\hline 11-3. Self-confidence toward Writing in English & 70 & 2.5 & 1.2 & 2.7 & 1.2 & 1.7 & + & 1.3 & & 2.3 & * & 0.4 & & 0.6 & \\
\hline 11-4. Self-confidence toward Reading in English & 70 & 3.0 & 1.2 & 3.2 & 1.2 & 2.1 & * & 0.4 & & 2.3 & $*$ & 1.4 & & 0.3 & \\
\hline $\begin{array}{l}\text { 13. Feeling able to learn at one's own pace in English } \\
\text { lessons using computers }\end{array}$ & 70 & 3.0 & 1.1 & 3.5 & 1.1 & 3.9 & **** & 1.5 & & 1.1 & & 2.1 & + & 2.8 & $*$ \\
\hline $\begin{array}{l}\text { 17. Being fond of practicing acting a dialogue with } \\
\text { one's partner }\end{array}$ & 70 & 2.7 & 1.1 & 3.1 & 1.3 & 3.6 & **** & 1.7 & & 3.2 & $* *$ & 0.8 & & 2.1 & $*$ \\
\hline $\begin{array}{l}\text { 18. Being eager to instruct each other in pronunciation } \\
\text { errors with one's partner }\end{array}$ & 71 & 2.7 & 1.1 & 3.4 & 1.2 & 4.6 & **** & 3.2 & ** & 3.3 & $* *$ & 1.7 & & 1.2 & \\
\hline
\end{tabular}

\subsubsection{Consideration of the Results}

The result of this study showed that the oral reading skill was improved through blended instructions and that of the personality group, 'Introverted unintelligent person', was much more improved as well as the personality group, 'Sociable hard-worker' than other two personality groups. Though there was no significant difference between the 'Introverted unintelligent person' and the 'Sociable hard-worker' in terms of the development of oral reading skill, such a development of the 'Introverted unintelligent person' is worthy of note, as it is hard to guess such a development of the 'Introverted unintelligent person' previously, compared with that of the 'Sociable hard-worker.'

The first factor which contributed to the development of the oral reading skill in both Experiment 1 and Experiment 2 was "Pronunciation of Passage." The important factors for the group, 'Introverted unintelligent person,' in terms of the oral reading performance were 'Sentence Stress' in Experiment 1 and 'Sense Reading' in Experiment 2. This can mean that the students came to notice the existence of sense groups in a passage and those semantic ties. It might have been due to each student's individual practice of listening to and completing the dialogue through virtual conversation with the video clips in the WBT courseware, thinking about the natural flow of conversation and sense groups of a passage. It can be said that the individual conversation practice with video clips in the WBT courseware helps develop the oral reading skill of the 'Introverted unintelligent person' and is an effective factor in a blended instruction.

Development of students' self-confidence on speaking English and motivation toward collaborative learning might have been caused by face-to-face communication 'in a classroom', for example, acting out dialogues in pair work, peer tutoring and assessment tasks. Development of students' self-confidence on listening English and motivation toward self-paced learning might have been caused by individual practice of listening to and completing the dialogue through virtual conversation with the video clips in the WBT courseware.

\section{Conclusion}

Through blended learning with WBT courseware in a junior high school, the students' oral reading skill was improved. Their self-confidence on speaking and listening English and motivation toward collaborative learning and self-paced learning were developed. These results are thought to have been brought by multiplier effects of each factor of blended instruction - the WBT courseware and the types of instruction. In this study, the authors verified the relationship between the development of the oral reading 
performance and the students' personality. The result showed that blended instruction is more effective on the personality group, 'Introverted unintelligent person', as well as the personality group, 'Sociable hard-worker', than other personality groups in terms of the oral reading performance and the important factors for the group were 'Sentence Stress' and 'Sense Reading'. This result will help develop the study on the effective blended instruction. A topic for future study is to conduct a further investigation on the effects of blended instruction on speaking skill and its relationship to the five-factor model of personality.

\section{References}

1 Allport, G. W., \& Odbert, H. S. (1936). Trait-names: A psycho-lexical study. Psychological Monographs, 47 (1. whole No.211).

2 Bonk, C. J. \& Graham, C. R. (2006). Handbook of blended learning: Global Perspectives, Local Designs. San Francisco: Pfeiffer Publishing.

3 Clark, J. M., \& Paivio, A. (1991). Dual coding theory and education. Education Psychology Review, 3(3), 149-210.

4 Davies, P. (1999). Learning through assessment: OLAL (on-line assessment and learning). 3rd CAA Conference Proceedings, Flexible Learning Initiative, 75-78.

5 Endou, T. (2005). Study on Improvement of Learning Instruction in High School. Workshop Report on Instruction and Research in Iwate Prefecture. Retrieved from http://www.iwate-ed.jp/db/db1/ken_data/center/h16 ken/h16_09b04.pdf. (in Japanese)

6 Fujishiro, N., \& Miyaji, I. (2007a). A Study on the Conversation Practice Blended with WBT and its Effectiveness in Junior High School. The 10th Conference of Japan Society for Studies and Educational Practice, 5-6 (in Japanese).

7 Fujishiro, N., Hiramatsu, S., Miyaji, I. (2007b). Effects of Communication Practice Utilizing the Digital Learning Materials Based on WBT for English Listening in the Blended Learning Approach. Japan Society for Educational Technology Journal, 31(Suppl.), 85-88 (in Japanese).

8 Fujishiro, N., \& Miyaji, I. (2007c). Effects of the 'Blended Learning' in Class Utilizing the WBT Courseware for English Listening. Supporting Learning Flow through Integrative Technologies (pp.235-238). Amsterdam: IOS Press.

9 Fujishiro, N., \& Miyaji, I. (2008). Effects on the Oral Reading Performance through the 'Blended Learning' in English Class Utilizing the WBT Courseware. The 16th International Conference on Computers in Education, Proceedings, 1, 427-431.

10 Fujishiro, N., \& Miyaji, I. (2009a). Effectiveness of Blended Instruction in Class on the Skills of Oral Reading and Speaking in English. Educational Technology Research, 32, 79-90.

11 Fujishiro, N., \& Miyaji, I. (2009b). The Effects of Blended Instruction Utilizing WBT Courseware and their Relationships to the Five-Factor Model of Personality. Proceedings of the 17th International Conference on Computers in Education, 472476. 
12 Gagne, R. M., Wager, W. W., Golas, K. C. \& Keller, J. M. (2005). Principles of Instructional Design. Wadsworth: A division of Thomson Learning.

13 Goldberg, L. R. (1992). The Development of Markers for the Big-Five Factor Structure. Psychological Assessment,4(1), 26-42.

14 Goodlad, S., \& Hirst, B. (1985). Peer tutoring: A guide to learning by teaching. London: Kogan Page.

15 Koike, I. (Ed.). (1994). New Trend of English Education Based on Studies on Second Language Acquisition. Tokyo: Taishukan. (in Japanese).

16 McAdams, D. P. (1992). The Five-Factor Model in Personality: A Critical Appraisal. Journal of Personality, 60(2), 329-361.

17 McGurk, H., \& Macdonald, J. (1976). Hearing lips and seeing voices. Nature, 264, 746-748.

18 Miyaji, I., You, K. \& Yoshida, K. (2005). The Effect through Instruction Blending e-Learning and Lecture. Japanese Society for Information and Systems in Education Journal, 22(4), 254-262 (in Japanese).

19 Mochizuki, H. (2004). Application of Shadowing to TEFL in Japan: The Case of Junior High School Students. A MA Thesis Presented to the Graduate School of Language, Communication and Culture, Kwansei Gakuin University (in Japanese).

20 Murakami, Y., \& Murakami, C. (2001). Handbook for BigFive. Tokyo: GakugeiTosho (in Japanese).

21 Nunomura, K., \& Murakami, Y. (1996). Effects of English Instruction and Personality Dimensions on Learning. Bulletin of Center for Education and Practice, Toyama University, 14, 41-45 (in Japanese).

22 Paulston, C. B. (1992). The sequencing of structural pattern drills, in Croft, K. (ed.), Linguistic and Communicative Competence. Clevedon: Multilingual Matters.

23 Pica, T., \& Doughty, C. (1985). Input and interaction through communicative language classroom: a comparison of teacher-fronted and group activities, in Gass, S.M. and Madden, C.G. (eds.), Input in second language acquisition. Rowley: Newbury House.

24 Rirers, W. M. (1972). Speaking in Many Tongues. Rowley, MA: Newbury House Publishers Inc.

25 Scanlon, E. (1997). Learning Science On-line. Studies in Science Education, 30(1), 57-92.

26 Takanashi, Y. (1992, June). Prerequisite for Communication Activities. Gendaieigokyouiku. Tokyo: Kenkyusha. (in Japanese).

27 Tamai, K. (2005). Study on Effects of Shadowing as Listening Instruction. Tokyo: Kazama-Syobou (in Japanese).

28 Tupes, E. C., \& Christal, R. E. (1961). Recurrent personality factors based on trait ratings (Tech. Rep. Nos. 61-67). Lackland. TX: U.S. Aeronautical Systems Division. 
29 Van Der Stuyf, R. R. (2002). Scaffoldings as a Teaching Strategy. Retrieved from http://condor.admin.ccny.cuny.edu/ group4/Van Der Stuyf/Van Der Stuyf Paper.doc.

30 Widdowson, H. G. (1978). Teaching language as communication. Oxford: Oxford University Press.

31 Wiggins, J. S., \& Trapnell, P. D. (1996). The Five-factor Model of Personality: Theoretical Perspectives. New York: The Guilford Press.

32 Wilson, D., \& Smilanich, E. (2005). The other blended learning. San Francisco: Pfeiffer. 